\title{
BIM Backed Decision Support System in the Management of Heritage Building
}

\author{
Muhammad Hadi Mustafa \\ Department of Quantity Surveying, Kuliyyah of Architecture and Environmental Design, International Islamic University Malaysia, 53100, \\ Gombak, Selangor \\ Email: hadimustafaphd@gmail.com
}

Maisarah Ali, Kamsiah Mohd Ismail,

Department of Civil Engineering, Kuliyyah of Engineering, International Islamic University Malaysia, 53100, Gombak, Selangor

Khairusy Syakirin Has Yun Hashim \& Mohamad Saifulnizam Mohd Suhaimi

Department of Quantity Surveying, Kuliyyah of Architecture and Environmental Design, International Islamic University Malaysia, 53100, Gombak, Selangor

\begin{abstract}
Historical buildings are always at risk to great danger strike by fire, flood and other potential disasters affecting the building conditions. Thus positive and continuous actions need to be taken to preserve the heritage buildings or else a country might lose its cultural heritage value. In managing historic buildings, managers are often faced with complex decision-making process due to limited or unavailability of reliable information. The absence of such information influenced the way decision making and problem-solving made by the managers. This paper aims to highlight the potentials of Building Information Modelling (BIM) as a decision support system for cultural heritage management. An embedded case study was conducted on Istana Balai Besar Kota Bharu, focusing on the changes of the historical building's layout to demonstrate the ontology. A measured drawing dated back in 1976 was used together with the terrestrial laser scanning activity performed presently on the physical building in creating a model in BIM environment. The result gives an overview about tracking information on changes within a historical building as part of cultural heritage management. This paper finds that by modelling the data captured by the 3D laser scanner and utilizing the existing data, BIM is capable of helping managers to retrieve, analyze and store important information in a more efficient and productive process. This exploration is substantial as a precursor to a much broader study on BIM for cultural heritage in the Malaysian context. As BIM is set to drive the construction industry, the finding made would be a catalyst for creating awareness to support the development of BIM for cultural heritage management in Malaysia.
\end{abstract}

(C) 2019 Penerbit UTM Press. All rights reserved

\section{Article History}

Received : 7 November 2018

Received in revised form : 24 March 2019

Accepted : 17 April 2019

Published Online : 30 April 2019

\section{Keywords:}

BIM, cultural heritage management, historic building, exploratory research, decision support system

\section{Corresponding Author Contact:}

hadimustafaphd@gmail.com

DOI: $10.11113 /$ ijbes.v6.n2.357

able to have faster and efficient process when it comes to making crucial decisions in managing problems. BIM approach, which emphasizes on the digitization of information, is believed to have many unexplored potentials in the area of heritage building
Technological advancement has enabled benefits in the area of decision support system for cultural heritage. Managers will be 
management. Allen, Cruz and Warburton (2017) believed that highly capable Decision Support System (DSS) which is now mostly computer, internet and cloud-based is underutilized. In Malaysia, the level of maturity of DSS such as BIM is considered low and slow (CIDB Report, 2016 and Zahrizan et al. 2013). Thus, investigating the potential of BIM is a continuous effort in Malaysian construction industry as an initiative to improvise the industry's practice. Although there have been a few number of publications on BIM for heritage buildings worldwide, not many have touched on the Malaysian heritage context. Therefore, this paper which employs exploratory embedded case study methodology aims to highlight the potentials of BIM as decision support system for cultural heritage management by providing an overview on how to utilize BIM in tracking the changes of a historical building's layout.

\section{Decision Support System}

In any process, information plays a major role. Information value depends on how it is applied and used. Tripathi (2011) suggested that an organization's success depends heavily on the organization's Decision Support System (DSS) adoption. The information generated from DSS will affect the decision-making process and the quality of decisions. There are many definitions for DSSs and their functions in decision-making process, such as data modeling, remote access to databases, data conversion, data verification and validation, textual data translation into a multilingual system, standardization of data formats and access methods, and integration of database management systems as further suggested by Tripathi (2011). The potential of each functions can be utilized for many purposes.

DSS can be defined as an application that processes and analyzes data and presents it so that users can make decisions more conveniently. According to Tripathi (2011), among the characteristics of a good DSS is that it can perform 'what if' and goal-seeking analysis.

Since construction industry is a data-dependent industry, therefore data must be managed efficiently with the right tool to ensure a project's success (Ismail, Bandi and Maaz, 2018).

BIM presently revolutionizing the construction industry and becoming the standard in several countries around the world because of its various advantages (Seghier et al.,2017). Due to the awareness and readiness for Industrial Revolution 4.0, there is an increasing need in adoption of innovative technological processes and development in Malaysia. Although the construction industry in Malaysia plays a crucial role in stimulating the economy, it lags behind other economic sectors. This is probably because of its unique features such as fragmentation and slow adoption of technology (Bean, Mustapa, and Mustapa, 2018). There have been many studies from many previous researchers highlighting the importance of using technological approach in day - to - day business activities, thus implying the importance to consider a DSS technology to ensure better productivity and efficiency for our construction and specifically, for heritage sector. The emergence of more advanced technologies nowadays have necessitate a much stronger emphasis on job competencies than ever before (Oladotun and Edosa, 2017).

\section{BIM as a Decision Support System (DSS) in Cultural Heritage Management}

Traditionally, historical buildings have subscribed to the belief that it reflects the identity of a nation and culture. Its existence is a proof for future generations of origins, civilization, and level of technology of the ancestors (Sodangi et al., 2014). The buildings such as the Taj Mahal and Hawa Mahal in India, the Colosseum in Italy, The Parthenon in Greece, Sultanahmet Mosque and Hagia Sofia in Turkey, St Basil's Cathedral in Russia, and The Forbidden Palace in China have proven to convey this message successfully. Throughout the buildings' lifespan, conservation by repairing the physical of the buildings was rampant (Rashid \& Ahmad, 2011). However, the rampant changes are giving serious effect on the historic buildings' documentation process. There is an increasing concern that some of the buildings are being disadvantaged by the unavailability of documents, which may also be exposed to risks such as inadequate and outdated information (Blinn \& Issa, 2017). Historical information and documents are important because it is the primary means (Arayici, 2013) to eventually guide a decision making process by property owners, site managers, public officials and conservators. In this regard, it is important for owners, managers and custodians, to know how to systematically and effectively evaluate, plan and implement the management program for their historical buildings. A well - preserved historical building improves the quality of life for all in the community, helps attract investment to the community (tourism product), contributes to regeneration and provides a source of local pride and sense of place.

Previous studies have reported that the practice of cultural heritage management should maintain as much as possible the original building structure and fabric. Base to this principle and aims to maintain the national heritage in "true nature", major challenges and issues, especially in judgment and decision-making, there is imperative need for decision-making activities to be carefully well-thought-out (Harun, 2011). Thus, the unavailability of historical data will pose more issues and causing more problems which may lead to project failure.

According to Allen, Cruz and Warburton (2017), "in recent times, DSS has been redefined as broader initiatives of knowledge transfer that comprise: i) a development process with active stakeholder involvement; and ii) an interactive (often internet/computer based) tool that is easy to use, has minimal data requirements, can be readily updated, and provides information access, model analysis and decision guidance. Decision support system aims to provide multiple benefits including improved communication, collaboration and learning amongst stakeholders and with the development team ".

The BIM technology can be considered as a powerful DSS that acts as a database tool which comprises of information-enriched 3D model. It is a technology that has improved the way buildings are analysed and managed (Calin et al., 2015; Baik et al., 2014). Similarly, to automotive and robotic industries which develop 
digital prototypes of vehicles and robots, Architectural, Engineering and Construction (AEC) industry are now able to provide an informative digital representation of a building before the first shovels hit the ground by using BIM. One of the most important feature of BIM is it can store information about the process involving the assembly of building components and spaces into a virtual representation of the building or facility (Lopez et al., 2018; Arayici, 2013) in the form of geometry (tangible data) and associated information (intangible data). In short, BIM can be used to document and store information efficiently and effectively, including data about culture, historical material and operational information (Carbonari et al., 2015; Nunez et al., 2015). By having this feature, the classic problem of having inadequate and outdated documentation for technical references (Ali et al., 2018; Blinn \& Issa, 2017; Volk et al., 2014) can be mitigated. BIM is anticipated to be an essential tool as a central database to support comprehensive data input for activity such as cultural heritage lifecycle management (Ali et al., 2018; Volk et al., 2014). Thus, it is also anticipated that BIM would be beneficial for various efforts such as preservation, adaptive re-use, and reconstruction.

BIM is not just a software, as Hardin (2009) put it, but a process that integrates all the building works and information to create a new way of thinking in the essence of not doing the same old things. The concept of BIM consists of integrating information and all previously dispersed data into the BIM model, which consists of structures and architecture design and other associated information regarding the buildings. BIM's primary objective is to eliminate the future work of recollection or reformatting of information about facilities; which is wasteful (Eastman et al, 2008). Hardin (2009) as cited in Mohamed Salleh et al. (2018) suggests that BIM is a virtual building model that contains smart technology that collects all information on building elements in the same server file that can be shared to increase communication and collaboration among the project team members.

As BIM's potential to model existing buildings that have heritage or cultural values to local people are increasingly being recognised (Calin et. Al., 2015; Volk et al., 2014; Baik et. al.,2013), building owners and facility managers have also seen tremendous benefits in handling their building using the approach (Carbonari et al., 2015; Volk et al., 2014; Baik et al., 2014). What is not yet clear is on the process of how BIM can be utilized as DSS in cultural heritage management. Thus, next section will demonstrate the process of data extracting, which the data will be used as information to support historical building managers in their decision-making process.

\section{Methodology}

In this paper, a descriptive embedded case study approach is adopted by comparing the techniques of getting building measurement and utilizing BIM approach in tracking the changes of a historical building's layout. Descriptive embedded case study is a method of analysing sub-units of the phenomenon to make the descriptions available to others (Bengtsson, 1999). According to Baxter \& Jack (2008), a case study method will be helpful when to study science, develop theories and involvements and when to evaluate programs, when the method is applied correctly. In order to study the potential of BIM as DSS for cultural heritage management, this paper chose to analyse the changes of layout for Balai Besar Kota Bharu (Kelantan) as the sub-units of analysis.

\subsection{Istana Balai Besar (the Grand Palace)}

Istana Balai Besar (the Grand Palace) is selected as the case study based on its cultural heritage significance. The palace was built by Sultan Muhammad II in 1844 and situated near to the Kelantan River. The Istana Balai Besar symbolized sovereignty and was used for official ceremonies such as inauguration and state official awards. The palace is a single-story structure made of Chengal wood and surrounded by palisades within an area of a 175,000foot square (Mohd Nor et al., 2017). Istana Balai Besar was previously known as the Istana Kota Lama and used to be the center for the government of Kelantan in the $18^{\text {th }}$ century. The building is now much valued for its elegant architectural features as shown in Figure 1.

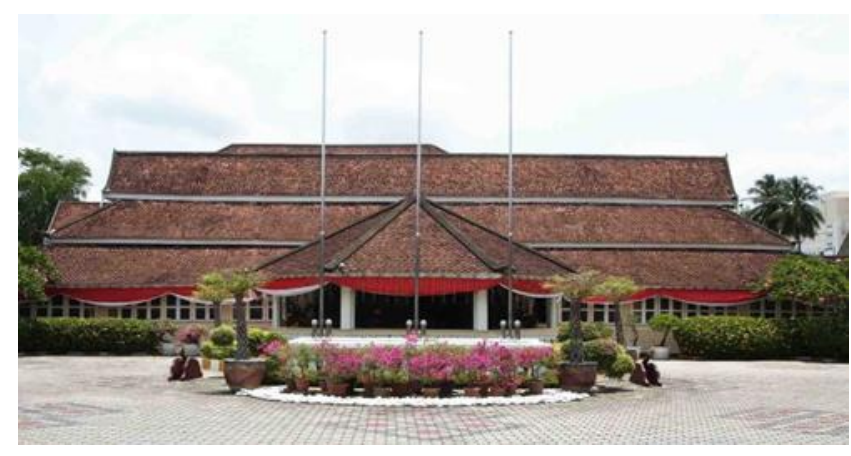

Figure 1 Balai Besar Kota Bharu

(https: / / sejarahkelantan.wordpress.com/tag/istana-balaibesar, 2018)

\subsection{Descriptive Embedded case study}

In the early days, documentation for cultural heritage buildings is driven by the information and sources used to build them and the real value proposition of it to analyse data (Baik et al., 2014). These conventional methods of architectural documentation on existing building are done manually by measured drawing (Gaidyte, 2010). Measured drawings are carried out to retrieve information such as dimension and the form of a building in the architectural study (Harun, 2011). This technique used measuring tools; a measuring tape, adjustable set square rulers, ladder, graph papers, and pens conducted in a large group of 10-20 people. The measurement recorded will be drawn on butter paper and redrawn for documentation. Nowadays, the conventional method of collecting data has inspired advancement in other technological tool known as Terrestrial Laser Scanner (TLS). TLS is an automatic tool that able to measure the $3 \mathrm{D}$ coordinates based on the object in $\mathrm{X}, \mathrm{Y}$, and Z-axes. These coordinates are based on the scanned surface that will reflect an encoded angular orientation in the form of point clouds, thus making the object collected into 3D data (Calin et al., 2015; Nunez et al., 2012). 
Two primary sources of building's data were gathered by comparing the old layout of the building taken in the year 1976 by a group of researcher from Universiti Teknologi Malaysia (UTM) and the latest layout of the building captured using TLS in the year of 2017 by researchers from International Islamic University Malaysia (IIUM). TLS was also used in this research as comparative tool because it allows accurate and faster capture of measurement to be modelled in the 3D environment (Shukor et al., 2015; Alkan \& Karsidag, 2012). This process is then followed by facilitating an iterative process of discussion and mapping of activities. The old layout of Istana Balai Besar was extracted from a measured drawings report dated May 1976 as shown in Figure 2, while Figure 3 shows the plan view of the extracted layout after being modelled using BIM platform by tracing method. The BIM platform used for this activity is Autodesk Revit.

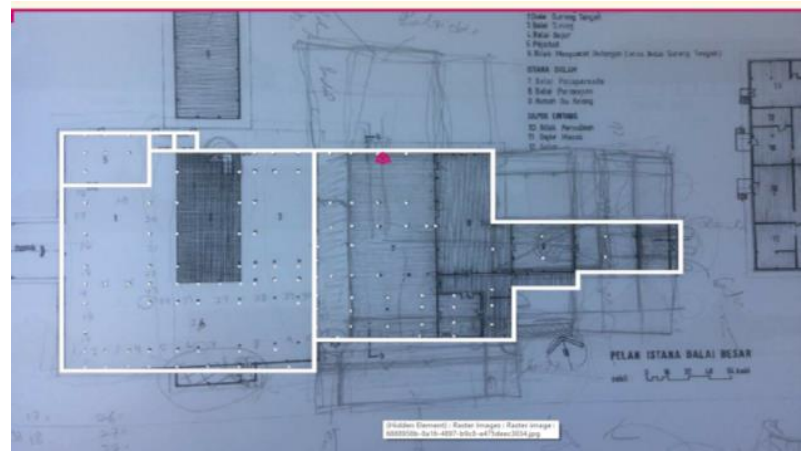

Figure 2 Istana Balai Besar layout (not to scale) in 1976 as per measured drawing report (Drawing report from UTM)

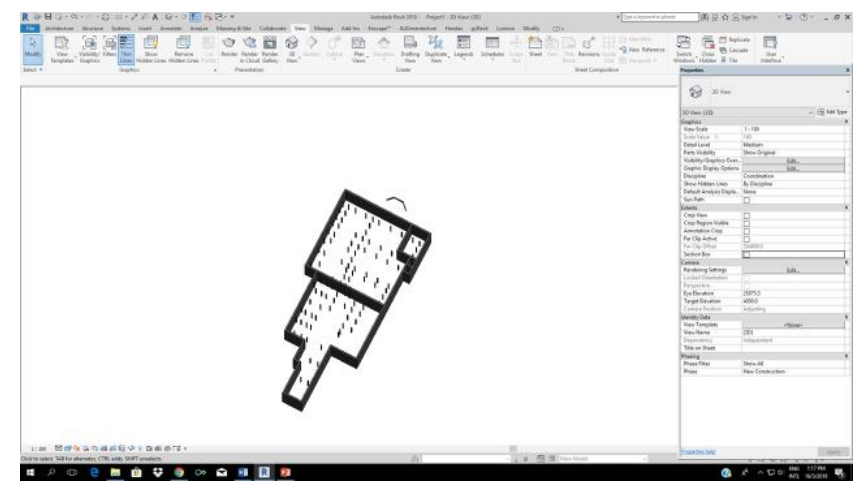

Figure 3 Istana Balai Besar layout (1976) as per BIM model (Authors' work)

\subsection{Process Carried Out For The Case Study}

This is the first study on Istana Balai Besar Kota Bharu using laser scanning activity. In conducting laser scanning activity, a technique known as 'tie points' was employed. 'Tie points' are represented by targets in which the laser scanner identified to minimize the 'noise' while capturing point clouds. Point cloud is described as the minimal level of detail based on its abstractions that produce a higher level of details (Alkan \& Karsidag, 2012).
The site was explored and the locations for the 'target' locations for the scanning process to take place was identified. Targets' used for laser scanning is a paper with portions of black and white on it as in Figure 4 to enable the laser scanner to detect the surface of the building effectively. The data collection is conducted outside the building using a Leica scan station P16 (Figure 5) to acquire the point clouds. Figure 6 shows the positioning of TLS around the building during the scanning process. The external building was scanned with a total of 26 total stations in a clockwise direction. After the scanning process was carried out, the data was then transferred into the data processor, and the point cloud cleaning and registration took place using Leica Cyclone 9.1.6 and Autodesk Recap.

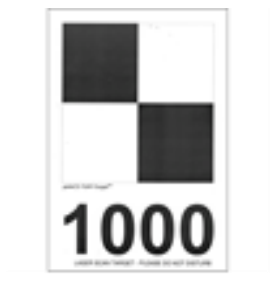

Figure 4 Example of black and white $(B \& W)$ target used with TLS

(https: / / www.point3d.us.com/product-page/tuff-targets-100pack)

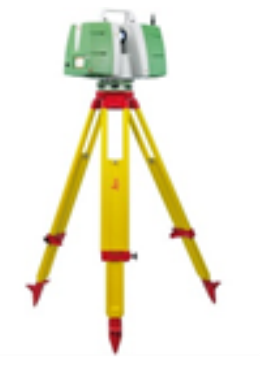

Figure 5 Leica Terrestrial Laser Scanner P16

(http: / / surveyequipment.com/leicascanstation-p16-3d-laserscanner /)

Point cloud data must be collected from several scans locations using a laser scanner to ensure full coverage of the studied object as shown in Figure 6. Laser scanners needed millions of accurate 3-D points which later underwent cleaning and registration process. Scans are often clouded with measurement noise due to reflection from building surface. Therefore to get a proper mesh, cleaning is necessary (Alkan \& Karsidag, 2012). Cleaning of data was carried out to eliminate irrelevant cloud points taken during the scanning process. Mesh is a raw format and is a collection of vertices, edges, and faces that describe the shape of the $3 \mathrm{D}$ object (Baik et al., 2014). Hence, registration process is carried out where the cleaned captured point clouds are converted into usable 3D information and formats such as .las, .pts or .rcp. This process is dependent on the type of TLS tool used during the scanning process since every TLS tool has specialized software to process their data accordingly. Providers such as Leica and Faro has dedicated software that helps to process, manipulate and analyze the enormous amount of point clouds captured. For this activity, 
researchers used P16 Leica scanner and the specialized software is known as Cyclone 9.1.6.

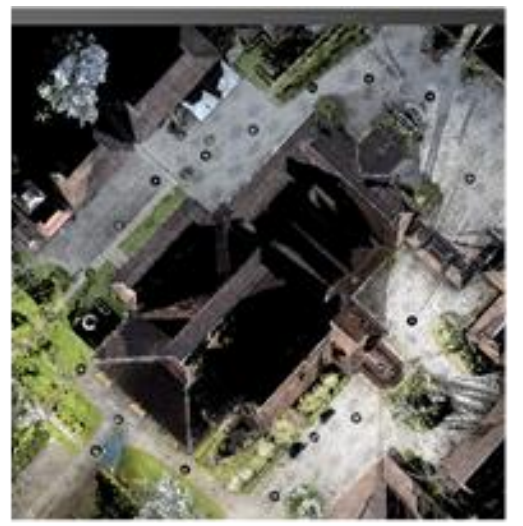

Figure 6 Positioning of Leica Terrestrial Laser Scanner P16 during scanning (Authors' work)

The study on the process continues as researchers superimposed the laser scanning data and measured drawings into BIM environment. This was done after the processing of point clouds by cropping some parts of the building such as the roof and wall from plan view so that a clear layout can be seen. The extracted layout is then modelled in a BIM platform for further analysis. Figure 7 shows the building's point clouds after it was cropped using Autodesk Reality Capture, and after the model's layout have been modelled into BIM environment using Revit (Figure 8 and 9). The layouts from both sources were then compared. Changes were observed on the buildings on its transition from the 1976 measured drawing up to the TLC output. It is anticipated that by knowing the changes of layout and area, managers can interpret the data and information into relevant contexts related to decision-making. The process to support the study of DSS for cultural heritage management is discussed in the next section.
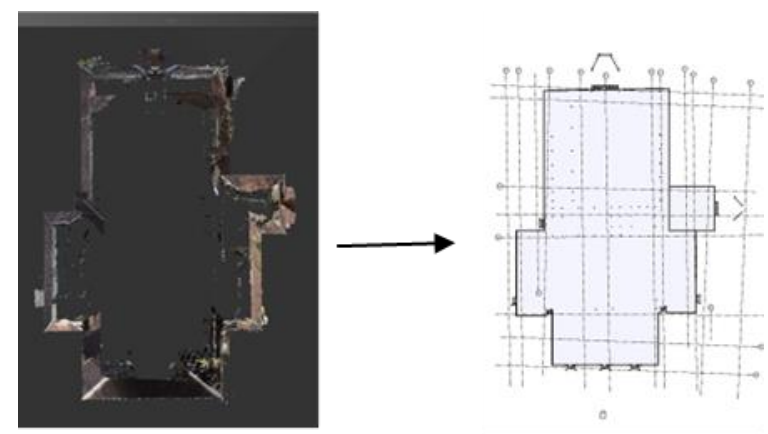

Figure 7 Building layout converted from point clouds to BIM using Revit (Authors' work)
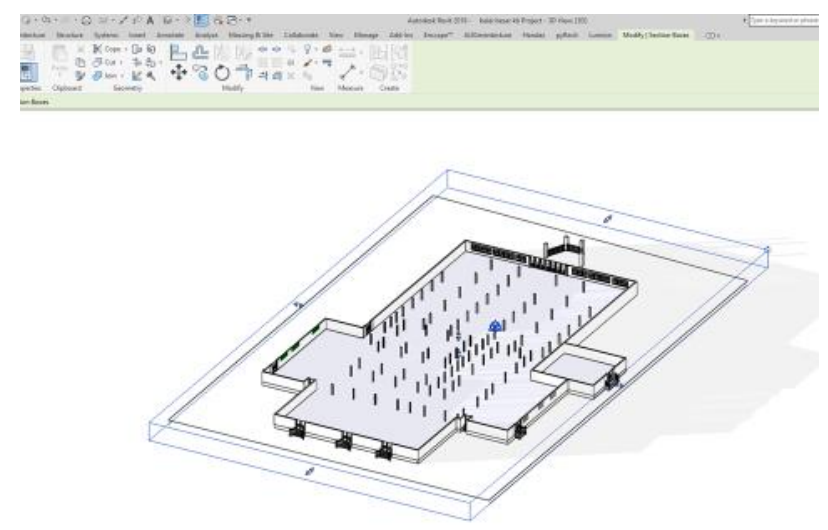

Figure 8 Building layout converted from point clouds to BIM using Revit in 3D view (Authors' work)

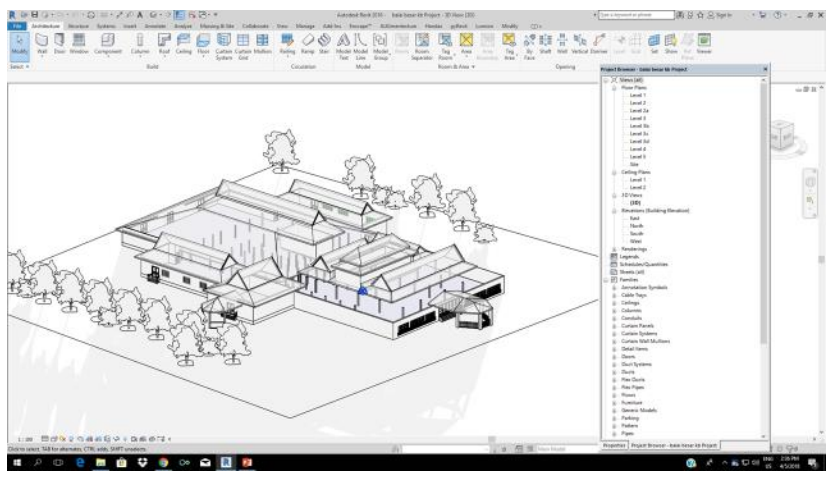

Figure 9 BIM model of Istana Balai Besar (2017) (Authors' work)

\subsection{Analysis and Discussions}

Prior to commencing the analysis of study, the building layouts are extracted and modelled into BIM environment. Following this, the comparison is made through observation and area calculation between them. Figure 10 shows the differences in the building layout, by comparison for the year 1976 (above) and 2017 (below). It is found that the layout is different from each other, deducing that the building had undergone a renovation in between 1976 to 2017. The front of the building at the entrance porch is maintained, but the size of the main hall has been made wider. The comparison also shows that there is an increase in space for storage at the rear of the building. This changes in the layout should be acknowledged by preservationist as it is an essential event in the building lifecycle. 


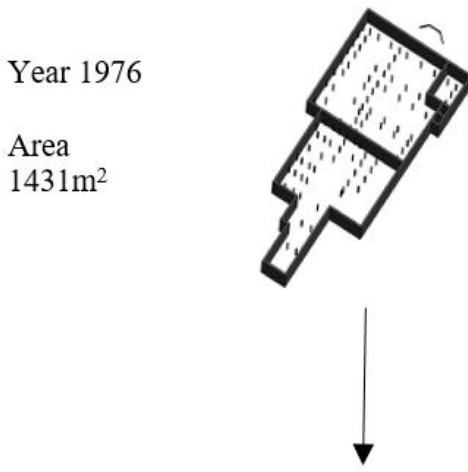

Year 2017

Area

$2345 \mathrm{~m}^{2}$

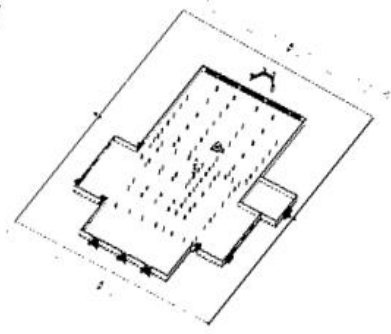

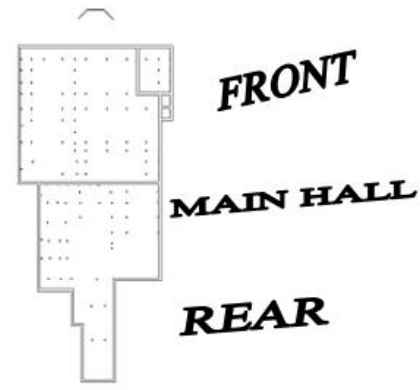

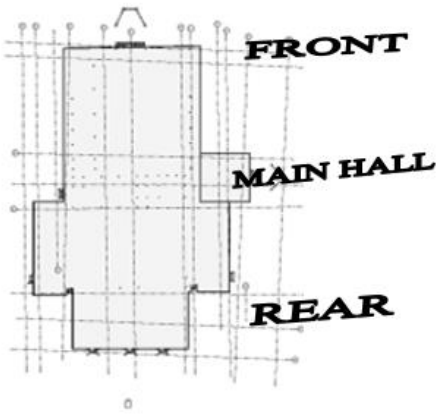

Figure 10 Building's layout and its transitional changes from 1976 to 2017

(Authors' work)

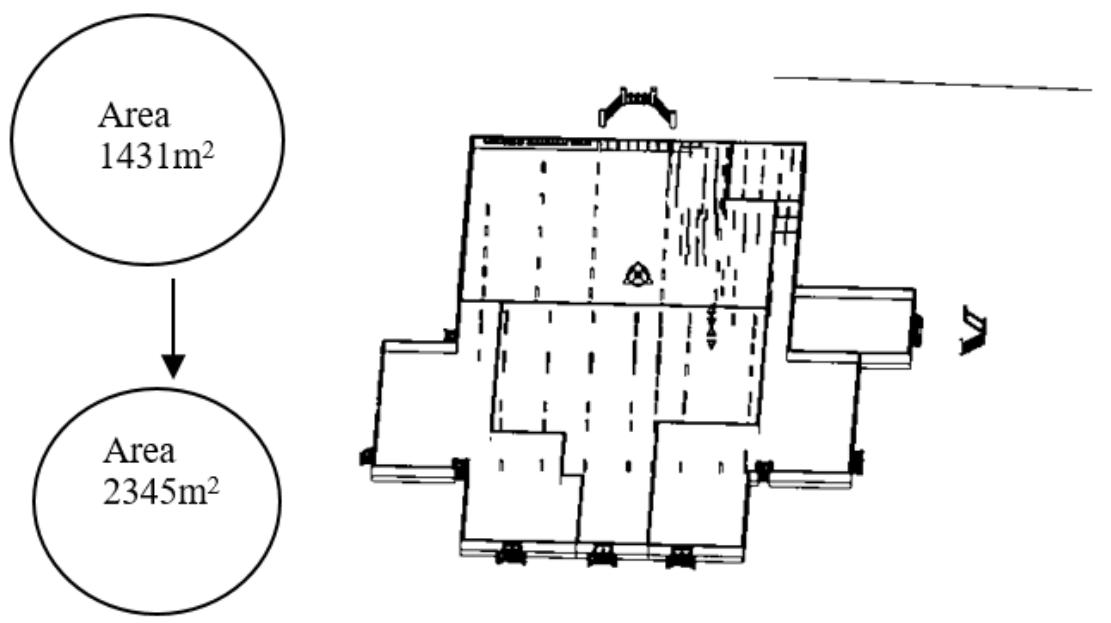

Figure 11 Superimposed layout of Balai Besar (Authors' work)

Figure 11 shows the comparison of the layouts of Balai Besar in 1976 that have been superimposed onto the Balai Besar in 2017. The inner layout of the year was extracted from measured drawing, while the outer layout modelled using the data collected using TLS in 2017 were used to calculate the difference between the areas of the layout using BIM platform. It showed that an additional $914 \mathrm{~m}^{2}$ in size. This result suggests the changes is due to a renovation that was carried out in between 1976 to 2017. Interestingly, the discovery of Istana Balai Besar has underwent a renovation is fascinating as researchers have managed to prove it scientifically. This information is significant, and this activity shows that such an event can be recorded with the utilization of 
DSS such as BIM. The process as described can complement the use of a wider range of more specific strategic planning and methodologies using information stored in the file, for future references (Ali et al. 2018; Carbonari et al., 2015; Volk et al., 2014).

DSS focuses on outcomes that require an understanding of how, and under what conditions. The information produced is interpreted and can be conveniently used by stakeholders (Matthews et al. 2011). The development and implementation of decision support systems (DSS) require knowledge and understanding of managerial decision making, levels of reasoning and problem solving and roles of managers. DSS as a tool can support project teams in the assessment of the facility by making it possible for them to choose the best working approach based on their data (Seghier et al., 2017). The desired long-term outcomes include priorities by providing technical and historical knowledge, demonstrating impacts on social, economic and environmental assets. These priorities are indicators and targets that need to be developed in advance in each outcome to assess the intensity of impacts to refine future planning.

The studies presented thus far provide evidence that primary benefit of the activity is that it helps to give output in a shorter time. The activity only took eight (8) hours to capture the raw data for measurement. The scanner also provides reliable measurement output as TLS provides a high level of measurement accuracy (Baik et al., 2014). Moreover, the conventional methods of data collection for buildings are complicated as it needs a lot of workforces, tedious to process and time-consuming. However, with the development of technology such as Building Information Modelling (BIM) and Terrestrial Laser Scanning (TLS), the process of measuring the existing building becomes easier, faster and safer (Ali et al.,2018; Alkan \& Karsidag, 2012; Gaidyte, 2010). With the help of this technological and intelligent modelling approach, it allows easy interpretation of the building and provides up to date information for documentation. In other words, the main strength of this activity is, it can provide recent and reliable information for documentation in a very short time and conveniently compared to the conventional method.

Besides, the activity carried out for this study promotes an innovative and advancement of methods in DSS for cultural heritage management by complementing the conventional method and technological advancement. This gives an opportunity for the earlier documentation of the building to be updated easily because the method was convenient as the scanning activity can be conducted from time-to-time. Thus, data and information of the building can be revised and administered easily to ensure its relevancy throughout its lifespan (Lopez et al., 2018; Ali et al., 2018; and Baik et al., 2014). The problem such as data void can be minimized as BIM has a user-friendly interface to allow practitioners to identify missing information and give a solution for it. This also opens up another opportunity for new job scope within the industry (Ali et al., 2018; Maina, 2018; Volk et al., 2014).

This finding has important implications for developing a systematic process in utilizing DSS such as BIM for cultural heritage management. The historical buildings in Malaysia are unique and not similar to other countries, thus requiring special attention and in-depth study. A clearer understanding is needed so the heritage of a culture can be appreciated by the people of the nation. The development of ground-breaking technology such as TLS and the introduction of technological approach workprocessing such as BIM must be fully-utilized by industry players, hence to produce more efficient results and highly reliable historical information.

\section{Conclusion and Recommendations}

This case study provided an important opportunity to advance the understanding of underutilized technology such as BIM in the context of cultural heritage of a nation. In this investigation, the aim was to assess the potential of DSS such as BIM for cultural heritage management. The results of this investigation show that effective management of complex problems needs to be recognized and implemented based on a systematic approach. The documentation process demonstrated is beneficial for preserving roots and identity purpose. Despite its exploratory nature, this study offers some insight on the importance of tracking historical data and information in accordance to scientific approach. It also shows how BIM can lead to better stewardship of the future in term of historic buildings. Although this explorative embedded case study only focuses and describes on the changes of layout in a historic building, other area remains crucial to ensuring stakeholders work in a coordinated manner across many management activities to achieve their desired vision for effective historical building management. Finally, researchers highly recommend that further study in the area of cultural heritage management for Malaysia's historical buildings to be conducted extensively in the future as there is abundant room for further progress in determining other potentials of BIM in this field. The following are some recommendations in order to excel the practicing of BIM for heritage works within the industry:

i. Organizing appropriate and adequate service training, workshops and seminars by relevant professional bodies and academia to enhance the acquisition of more BIM and technological skills and experience to enhance the ability to perform duties related to the use of BIM for historical buildings.

ii. BIM for historical buildings practitioners in Malaysia should not just settle with the roles and functions of the profession but should also be familiar with the roles and functions of other professionals in the conservation and preservation field.

iii. BIM for historical buildings practitioners should ensure that they possess competencies that include personal qualities, core competencies, and process competencies. The qualities should include independence, adaptability, willingness to learn, and ability to reflect on what has been achieved and what has not been achieved. A professional's core skills should include the ability to present clear and validated information, critical analysis, 
computer literacy, business awareness, prioritization, negotiation, and managing ambiguities and complexity.

\section{Acknowledgments}

This research was supported by a grant (TRGS16-03-003-0003) from the Ministry of Higher Education Malaysia (MOHE). This research is also supported by Kuliyyah of Architecture and Environmental Design (KAED) and Kuliyyah of Engineering of International Islamic University Malaysia.

\section{References}

Abdul Rashid, R., \& Ahmad, A. G. (2011). Overview Of Maintenance Approaches Of Historical Buildings In Kuala Lumpur - A Current Practice. Procedia Engineering. 20: 425-434. https://doi.org/10.1016/j.proeng.2011.11.185

Abdul Shukor, S. A., Wong, R., Rushforth, E., Basah, S. N., \& Zakaria, A. (2015). 3D Terrestrial Laser Scanner For Managing Existing Building. Jurnal Teknologi. 76(12): 133139.https://doi.org/10.11113/jt.v76.5895

Allen W, Cruz J, Warburton B (2017) How Decision Support Systems can Benefit From A Theory Of Change Approach. Environmental Management, https://dx.doi.org/10.1007/s00267-017-0839-y

Ali, M., Ismail, K., Suhaimi, M.S, Hashim, K.S.H.Y, and Mustafa, M.H., (2018), Heritage Building Preservation through Building Information Modelling: Reviving Cultural Values through Level Of Development Exploration. Journal of the Malaysian Institute of Planners, $\begin{array}{llll}\text { Volume. } & 16(2): & 62 & -72 .\end{array}$ http://dx.doi.org/10.21837/pmjournal.v16.i6.461

Ali, M., Ismail, K., Hashim, K.S.H.Y, Suhaimi, M.S, and Mustafa, M.H., (2018), Historic Building Information Modelling (HBIM) For Malaysian Construction Industry. Journal of the Malaysian Institute of $\begin{array}{llll}\text { Planners. } & 16(3): & 332 & -343 .\end{array}$ http://dx.doi.org/10.21837/pmjournal.v16.i7.522

Alkan, R. M., \& Karsidag, G. (2012). Analysis of The Accuracy of Terrestrial Laser Scanning Measurements. FIG Working Week 2012 Knowing to Manage the Territory, Protect the Environment, Evaluate the Cultural Heritage, (May 2012), 16.

Baik, A., Alitany, A., Boehm, J., \& Robson, S. (2014). Jeddah Historical Building Information Modelling "JHBIM"; Object Library. ISPRS Annals of Photogrammetry, Remote Sensing, and Spatial Information Sciences, II-5(May), 41-47. https://doi.org/10.5194/isprsannals-II-5-41-2014

Baxter, P., \& Jack, S. (2008). Qualitative Case Study Methodology: Study Design and Implementation for Novice Researchers. The Qualitative Report. 13(4): 544-559. Retrieved from https://nsuworks.nova.edu/tqr/vol13/iss4/2

Bengtsson P. (1999), Multiple Case Studies- Not Just More Data Points?!. Term Paper In Graduate Course in Research Methodology, University of Karlskrona Ronneby. Spring 1999. doi=10.1.1.30.9769

Blinn, N., \& Issa, R. R. A. (2017). Utilisation of Drawing Management Software To Enhance BIM Educational Experiences. BIM Academic Symposium. 0: 1-8.
Calin, M., Damian, G., Popescu, T., Manea, R., Erghelegiu, B., \& Salagean, T. (2015). 3D Modeling for Digital Preservation of Romanian Heritage Monuments. Agriculture and Agricultural Science Procedia. 6: 421428. https://doi.org/10.1016/j.aaspro.2015.08.111

Carbonari, G., Stravoravdis, S., \& Gausden, C. (2015). Building Information Model Implementation For Existing Buildings For Facilities Management: A Framework And Two Case Studies. 149: 395-406. https://doi.org/10.2495/BIM150331

Cheong, Y. Y., \& Nur Emma Mustaffa. (2017). Critical Success Factors for Malaysian Construction Projects: An Investigative Review. International Journal of Built Environment and Sustainability. 4(2): 93-104. https://doi.org/10.11113/ijbes.v4.n2.180

Eastman, C. Teicholz, P. Sacks, R., \& Liston, K. (2008). BIM Handbook A Guide to Building Information Modeling for Owners, Managers, Designers, Engineers, and Contractors. John Wiley \& Sons, Inc.

Eisenhardt, K. M., \& Graebner, M. E. (2007). Theory Building From Cases: Opportunities and challenges. The Academy of Management Journal. 50(1): 25-32. https://doi.org/10.5465/amj.2007.24160888

Gaidytè, R. (2010). 2D and 3D Modeling Comparison, 1-38. Retrieved from http://brage.bibsys.no/hig/bitstream/URN:NBN:nobibsys_brage_12669/1/Gaidyte,R..pdf

Hardin, B. (2009), BIM and Construction Management: Proven Tools, Methods and Workflows, Canada:Wiley Publishing Incorporated.

Harun, S. N. (2011). Heritage Building Conservation In Malaysia: Experience And Challenges. Procedia Engineering. 20: 41-53. https://doi.org/10.1016/j.proeng.2011.11.137

Ismail, S. A., Bandi, S., \& Maaz, Z. N. (2018). An Appraisal into the Potential Application of Big Data in the Construction Industry. International Journal of Built Environment and Sustainability. 5(2): 145-154. https://doi.org/10.11113/ijbes.v5.n2.274

Jones C, Cowan P, Allen W (2012) Setting Outcomes, And Measuring And Reporting Performance Of Regional Council Pest And Weed Management Programmes. Landcare Research, Lincoln, New Zealand

Kidder, T. (1982). Soul of a New Machine. New York: Avon.

López, F., Lerones, P., Llamas, J., Gómez-García-Bermejo, J., \& Zalama, E. (2018). A Review of Heritage Building Information Modeling (H-BIM). Multimodal Technologies and Interaction. 2(2): 21. https://doi.org/10.3390/mti2020021

K.B. Matthews, M. Rivington, K. Blackstock, G. McCrum, K. Buchan, and D.G. Miller. 2011. Raising the bar? - The Challenges Of Evaluating The Outcomes Of Environmental Modelling And Software. Environ. Model. Softw. 26(3) (March 2011): 247-257. DOI=http://dx.doi.org/10.1016/j.envsoft.2010.03.031

Maina, J. J. (2018). Barriers to effective use of CAD and BIM in Architecture Education in Nigeria. International Journal of Built Environment and Sustainability. 5(3): 175-186. https://doi.org/10.11113/ijbes.v5.n3.275

Mazzanti, Massimiliano, 2002. "Cultural Heritage As Multi-Dimensional, Multi-Value And Multi-Attribute Economic Good: Toward A New Framework For Economic Analysis And Valuation," Journal of Behavioral and Experimental Economics (formerly The Journal of Socio-Economics), Elsevier. 31(5): 529-558. 
Mohamed Salleh, R., Mustaffa, N., Abdul Rahiman, N., Tajul Ariffin, H., \& Othman, N. (2019). The Propensity of Building Information Modelling and Integrated Project Delivery in Building Construction Project. International Journal of Built Environment and Sustainability. 6(1-2): 83-90. https: / / doi.org/10.11113/ijbes.v6.n1-2.386

Mohd-Isa, A. F., Zainal-Abidin, Z., \& Hashim, A. E. (2011). Built heritage maintenance: A Malaysian perspectives. Procedia Engineering. 20: 213-221. https: / / doi.org/10.1016/j.proeng.2011.11.158

Mohd Noor, N., Kamaruddin, Z., Abdullah, A., Abdullah, A.A., Eusoff, S.S. and Mustafa, M.H. (2018), "Using Terrestrial Laser Scanner For Malay Heritage Documentation: Preliminary Approach to Istana Balai Besar, Kelantan”, International Journal of Development and Sustainability. 7(6): 1886-1897.

Núñez Andrés, A., Buill Pozuelo, F., Regot Marimón, J., \& de Mesa Gisbert, A. (2012). Generation of Virtual Models Of Cultural Heritage. Journal of Cultural Heritage. 13(1): 103-106. https: / / doi.org/10.1016/j.culher.2011.06.004

Oladotun, A. J., \& Edosa, O. M. (2017). The Need for Professionalism and Competencies in the Construction Industry. International Journal of Built Environment and Sustainability. 4(1): 10-16. https: / / doi.org/10.11113/ijbes.v4.n1.154
Seghier, T. E., Lim, Y. W., Ahmad, M. H., \& Samuel, W. O. (2017) Building Envelope Thermal Performance Assessment Using Visual Programming and BIM, based on ETTV requirement of Green Mark and GreenRE. International Journal of Built Environment and Sustainability. 4(3): 227-235. https: / / doi.org/10.11113/ijbes.v4.n3.216

Sodangi, M., Khamdi, M. F., Idrus, A., Hammad, D. B., \& Ahmedumar, A. (2014). Best Practice Criteria For Sustainable Maintenance Management Of Heritage Buildings in Malaysia. Procedia Engineering. 77: 11-19. https: / / doi.org/10.1016/j.proeng.2014.07.017

Tripathi, K. P. (2011). Decision Support System Is a Tool for Making Better Decisions in the Organization. Indian Journal of Computer Science and Engineering. 2(1): 112-117.

Volk, R., Stengel, J., \& Schultmann, F. (2014). Building Information Modeling (BIM) For Existing Buildings - Literature Review And Future Needs. Automation In Construction. 38(October 2017): 109-127. https: / / doi.org/10.1016/j.autcon.2013.10.023

Yusuf Arayici, (2008) "Towards Building Information Modelling For Existing Structures". Structural Survey. 26(3): 210-222, https: / / doi.org/10.1108/02630800810887108 